\title{
American Studies in Romania
}

\section{(2) OpenEdition \\ Journals}

Electronic version

URL: https://journals.openedition.org/ejas/346

DOI: 10.4000/ejas.346

ISSN: 1991-9336

Publisher

European Association for American Studies

\section{Electronic reference}

Ioana Luca, "American Studies in Romania", European journal of American studies [Online], 1-1 | 2006, document 16, Online since 11 January 2006, connection on 09 July 2021. URL: http://

journals.openedition.org/ejas/346 ; DOl: https://doi.org/10.4000/ejas.346

This text was automatically generated on 9 July 2021.

Creative Commons License 


\section{American Studies in Romania}

American Studies at the University of Bucharest

1 The idea of teaching American Studies and founding a program in American Studies was first voiced in the long meetings of faculty and students held at the University of Bucharest soon after the collapse of the communist regime. The proposal was one of many that reflected the spirit of reform and hope for radical changes at the outset of Romania's transition to democracy. The absence of institutional structures other than English departments and the lack of resources, tradition and experience conspired against the complete and immediate feasibility of the project at that moment. However in the early 1990s, within the English department at the University of Bucharest, a new emphasis was laid on American studies and an exciting course was introduced to students, majoring in English, i.e. American Civilization. Before 1989, only American literature was taught in the curricula, a one semester course, or an elective for senior students.

2 The introduction of American Civilization courses for English students (major or minor) was a groundbreaking success, and it set in motion the numerous achievements in the field of American studies which were to come in the following years. First a more extensive study of American Literature and Civilization (four semesters) became the predominant component for those who took English as a minor and chose the American module. For me, an undergraduate student at that moment, and for all my generation, it all started with Professor Rodica Mihaila's course in American Civilization and her book The American Challenge: An Introduction to the Study of American Civilization (1994), the "blue bible" as we used to call it. Her innovative, interdisciplinary and up-to date approach fascinated us and also enticed us to specialize in this field; moreover, and perhaps more importantly, it successfully challenged the old rigid institutional structures. As a result of Prof. Mihaila's relentless efforts, in 1996 the first graduate program in American Studies opened its doors at the School of Foreign Languages and Literatures. I was among the fortunate fifteen pioneers to embark, from the very beginning, upon this new field in the Romanian academia. The graduate program offered us a module-based curriculum, which could accommodate a large variety of topics, such as Reconfiguration of American Studies, Film Studies, Sociology, Mass Media and Popular Culture, Gender and Psychoanalysis, Postmodernism and 
Visual Arts or U.S. Political Traditions ; these were just some of the courses offered by faculty coming from different departments of our university and from other academic institutions in Bucharest or by Fulbright Visiting Scholars. The program was intended to analyze American civilization in its origins, ideals, and historical development. Its inter- and trans-disciplinary approach, utilizing, besides history, the resources of literature, political science, economics, sociology, philosophy, and the fine arts, offered us the flexibility to work across discipline and address American culture through a variety of perspectives and methodologies. Coming with a rigid background (most of us were graduates of philology, while only a few were graduates of economics, medical school, or history), the program broadened our horizons and triggered in all of us an awareness of contemporary issues, be they political, economic, or related to human rights. The goal of the program was to integrate knowledge in a way meant to enable the students to grasp past and present cultural patterns of American society while pursuing their own special interests concerning that culture. The structure of the program accordingly provided ample opportunity for creative diversity.

Three of the MA graduates joined Prof. Mihaila in what was to become the American studies team, and later the American studies Center at the University of Bucharest.

The new step in catching up with the long tradition of American Studies departments elsewhere in Europe and in sharing our enthusiasm and fervor for this field, was founding an undergraduate program in American Studies at the University of Bucharest. Institutionalizing American Studies at the undergraduate level was a challenge and, more often than not, a continuous struggle with the old rigid and ossified university system, lack of financial resources, and countless delays and administrative difficulties in including American Studies on the national list of specializations.

5 Founded in 1999, the B.A. in American Studies at the School of Foreign Languages in the University of Bucharest has served as a center for creative multi- and interdisciplinary study and teaching about the United States. It has attracted some of the most talented and intellectually adventurous students at the Faculty of Foreign Languages, by offering them a prestigious minor (as of 2004, a major) at the undergraduate level; the success of the program is best proven by this year's admission competition, the highest competition at the School of Foreign Languages, with 11 candidates competing for one government subsidized seat. In 2003 the program awarded the first B.A. degrees to its first 11 students. At least three of them continued their studies in PhD programs in the U.S. Since 1999, the program has enrolled roughly 200 students for the B.A. in American Studies. However it was only last year that "American Studies" was finally included on the national list of specializations: this was the outcome of a long struggle which brought official recognition to an interdisciplinary field established long ago in the Western world.

Organized and coordinated by Professor Mihaila, the program director, the purpose of the American Studies program at the undergraduate level is to provide students with the opportunity to gain a broader understanding of the United States through the study of diverse aspects of American culture, the use of several disciplines and approaches, and the development of a comprehensive view of America's past experience and present situation. The three main modules in the program, i.e. Culture and Values, Society and Communication, and History and Politics, help students understand changes in American social and political institutions, forms of economic organization, 
competing myths and ideologies, and responses to world politics that have developed in the American experience. In order to meet the requirements of the Romanian educational system (and the EU/Bologna Reform) as well as the present job-market needs, the program also offers a philology component together with an elective teacher-training module, which enable students to become specialists in American studies but also translators or teachers of English ${ }^{1}$.

7 The program has sought to overcome some of the limitations of present day Romanian institutional politics and align itself with European and American universities, where such programs have a long tradition; this has been attempted mostly by drawing on the human resources of various departments, creating alliances and pooling resources among teachers and scholars from various disciplines whose intellectual interests are focused on the U.S.

8 The American Studies Program has enjoyed the participation and support of American Fulbright scholars, whose innovative, inspiring and challenging courses on Film Studies, Mass Media and Advertising, Law, or Journalism have become cornerstones for both students and young scholars willing to gain valuable fresh insight into the various topics covered.

9 Colleagues from other departments and institutions (History, Political Science, The Academy of Economics, The Center of Contemporary Art) have always participated enthusiastically in the program and have offered, in spite of the difficulties that a new program unfortunately entails, core courses in American Law, American History, The American Constitution from a Historical Perspective, Contemporary Visual Arts, Business Trends. Well-established researchers, as well as promising young scholars from the English department, have embarked on this new challenge and elaborated new and highly stimulating courses and workshops. One may mention here such courses as Anthropology and American Cultures, Political Doctrines, Native American Culture, AfricanAmerican Culture, Language and Society, Popular Culture, American Utopias, American Philosophy, U.S. Cultures in the Era of Globalization or American Ethnic Literature.

10 Moreover, lectures and film series have been constantly organized, with a view to giving students and faculty the opportunity to meet and explore together major questions about American culture and society in a more informal context. The flexible module-based program has accommodated a number of Fulbright Scholars in various fields of study, so that not only the program is highly interdisciplinary, but also there is a wealth of direct experience for students. A rich (and growing) library, constantly supported by the U.S. Embassy in Bucharest, a multimedia system and a web page (www.american-studies.ro) with an active forum and permanently updated information also add to the attractiveness of American Studies in Bucharest.

11 If the graduate programs in Bucharest, Iasi (1996) or Cluj (1997) started almost simultaneously and independently one from the other, the burgeoning interest in founding undergraduate programs in many university centers was also galvanized by the active role the Romanian Association for American Studies (founded in 1999) has played in promoting and developing American Studies in Romania. The Association has brought together scholars and specialists in the field from all over the country, creating a strong community and has thus provided a much needed forum for discussion and clearing house for information about American Studies and related activities in Romanian cultural/educational institutions and research centers throughout the country. Through the e-list, the biannual RAAS-Fulbright Conferences 
and workshops, the Association has succeeded in being both an initiator and a driving force for the proliferation of American Studies programs throughout the country. It has been active in providing a site for an exchange of ideas and experiences between various universities about the EU/Bologna reform and the teaching of American Studies at the undergraduate and graduate level.

American Studies at Babes-Bolyai University, Cluj (Marius Jucan)

The inauguration of the B.A program in American Studies at the Babes-Bolyai University in Cluj reveals itself as a fortunate opportunity to realize the unprecedented growth of academic specializations in our University within the time span of the last decade, along with the intellectual commitment of researchers and professors determined to carry out the demanding scientific and cultural tasks of academic modernization.

The emergence of American Studies should be regarded as natural in the framework of an already established and accredited specialization-international relations and European Studies. The foundation for the emergence of this B.A. specialization at Babes-Bolyai University Cluj, was laid in 1997, when an interdisciplinary master degree in American Studies was established, this being subsequently included among the master programs of the Faculty of European Studies (in 1999). The master degree enjoyed the support of many prominent personalities within the faculty, the university, and from outside the academic environment. The partnerships developed since the establishment of the master program will be continued and extended with the creation of this B.A. in American Studies (2004), international cooperation being one of the pillars upon which academic performance and competitiveness is based. The most enduring and fruitful relationships have been those with the Fulbright Commission and the Romanian and American Studies Association, with Michigan State University, Plymouth State University, as well as with the American Studies Seminar in Salzburg. These partnerships, following in the footsteps of those established by European studies -which resulted in joint and double degree programs for the B.A. and M.A. level-will yield similar results leading to a better understanding of the complex realities of contemporary American society. These studies, beyond their mediatic appearance, actually refer to more than just history, literature, politics or economics-they deal with the intertwining of the American and European realities pertaining to the two most significant actors on the contemporary world stage.

The interdisciplinary character, the teamwork, the constant updating of the scientific discourse mean not only the acknowledgement of a new specialization, but also the leading principles upon which this has been built. American-European modernity should be setting the pragmatic basis of the contemporary world; thus, this specialization addresses not only high school graduates, but also different categories of specialists interested in acquiring knowledge from a different and innovative field, motivated by a necessity imposed by the pragmatic world we live in. The idea of political, military, economic and, why not, cultural hegemony may also have been one of the sparks which ignited the interest for American Studies. All these elements cannot be simply tackled at a journalistic level; they need a foundation of academic institutionalization.

American Studies at Al. Ioan Cuza University, Iasi (Iulia Blanutà)

15 Traditionally, there has always been a one-year course in American Literature for senior students, acquainting them not only with the literature but also with other 
aspects of the culture of the United States. Beside this course that functions as a compulsory topic of study, the department has offered students a number of optional courses dealing with specific aspects of American culture.

After 1995, the English department started a one-year (2 semesters) M.A. program, later to be developed in a two-year (4 semesters) M.A. program in American Cultural Studies, with 11 students accepted with governmental tuition and around 15 students paying their own tuition. Though organized under the umbrella of the Faculty of Letters in Iasi, this is more an interdisciplinary program since, beside the courses proposed by the professors from the English department, there is a constant co-operation with other departments in the University (History, Political Science, Philosophy and Journalism), the students enjoying a variety of perspectives on American culture. Thus, the courses offered by the department cover areas like American Poetics, Historicity and the Canon, Feminism, American History, American Art, Postmodernism, American English, Multiculturalism, and Film Studies, while students can also attend courses such as American Philosophy, Journalism, The American Political System, and Pragmatism.

Starting in 2004, the Department of English also organized a B.A. in American Studies as an option for students who chose English. In the first year 25 students chose this new specialization.

The BA was first structured on four years (eight semesters) and now it is restructured on three years (six semesters), because of the Bologna educational reform. Each year the students are offered a package of compulsory courses organized in Cultural Studies (Introduction to American Studies, Ethnicity, American Art, Gender Studies, Critical Approaches and American Modern and Postmodern Theory), Literary History, Language, American History, Political Institutions, Society and Communication (American Economic System, American Political System, Mass-Media, American Constructivism) and a Practical Course, completed by a package of optional courses that cover more specific aspects of American culture (The American South, The American Modern and Postmodern Short Story, Pop Culture, Science Fiction, the Language of Advertising, American Regionalism).

19 In order to complete their formation and offer them more opportunities on the job market after they graduate, the B.A. curriculum also includes the Methodology package, which is a set of courses and practical activities that are compulsory for all those who want to become teachers of English.

American Studies at Ovidius University, Constanta (Ludmila Martanovschi)

Starting with the 2005-2006 academic year, students who opt for undergraduate studies at Ovidius University, Constanta have the chance to select the major in American Studies at the Faculty of Letters. This is a three-year undergraduate program followed by a three-semester graduate program in Anglo-American Studies focused on both British and American culture.

21 High school graduates interested in studying in English found the interdisciplinary agenda of American Studies not only challenging, but also capable of ensuring a pragmatic education for their prospective careers. After a most serious exam, fifty-four students became students in American Studies. The English Department is fully prepared for the future students eager to discover the United States of America, as the American Studies BA program gives a comprehensive coverage of many aspects of American culture and civilization as well as of the American economic, political, and administrative system. Proficiency in English remains a pre-requisite since all courses make use of English as the language of the bibliographical material and of the class 
activities. Besides, students learn a second foreign language of their choice (German, Spanish, or Portuguese).

For the past six years, some of the English Department faculty has already taught variants of the core courses of the American Studies undergraduate program as electives in the English Major BA program. Thus, the foundation for the upcoming American Studies BA program has already been laid. In the curriculum valid this fall, besides American Literature, the philological module includes Developing Skills in Speaking, Listening and Writing English and American Language for the three years of study along with other specialized courses such as Contemporary Critical Theory in the first year or Language and Society in the third. The socio-cultural module offers first-year students Introduction to American Studies and U.S. History, second-year students do U.S. Geography, American Philosophy, "Media Studies" and "Popular Culture," while third-year students do U.S. Religion and Contemporary Arts. The wide range of elective courses further consolidates the students' knowledge of, and skills in, specific areas of interest. Going from courses such as American Political System and Institutions, US Constitution, Ethnic Studies in the first year, to Gender Studies, History of U.S. Press in the second year, and Film Studies, Contemporary American Theatre, US and Globalization in the third year, the students have the chance to get acquainted not only with most relevant topics in the field, but also with the expertise of the professors, associate-professors and assistant-professors at Ovidius University - Constanta as well as with visiting Fulbright lecturers.

American Studies at University of West, Timisoara (Cristina Cheveresan)

The beginning of the academic year 2004-2005 witnessed the fulfillment of a dream: the English Department managed to devise a new and innovative MA program, meant to cover as many areas connected to American Studies as currently possible. Thus, benefiting from a close collaboration with the Political Science Department, this initiative is aimed at offering a panoramic view of the American socio-political and cultural space, as well as detailed outlooks on its specific issues. Graduates in letters, philosophy, journalism, political science etc. who are proficient in English are invited to enlarge their knowledge of the 'American Dream' by means of attending series of lectures and seminars focusing on a large variety of study-topics.

The American Studies postgraduate specialization functions according to an interdisciplinary model of presentation and analysis: American culture, civilization and literature come to meet history, geography, religion, as well as gender and media studies or human rights in what is intended as an original and highly interactive program regarding the United States of America. This generous plan sets itself to open pathways to a better understanding of Transatlantic stereotypes and controversy, as well as to an accurate evaluation of the existing similarities and differences between American and European cultural patterns.

The objectives of this ambitious project are utterly diverse : offering the MA students solid knowledge of the above-mentioned fields of American Studies, it envisages their ulterior involvement in research, as well as the development of their analytical skills by means of comparative approaches. The students will be able to apply the acquired theoretical knowledge in practical situations typical of the American way of thinking and acting, in the context of their frequent meetings with foreign lecturers. 
Even if not all universities around the country have American Studies graduate or undergraduate programs, American Studies has become an important component of their curricula (in the Universities of Craiova, Galati, Oradea). In Baia Mare, for instance, despite the massive cuts in teaching time that the new EU-compliant 3-year formula has engendered (shrinking study time from 4 to 3 years), the faculty have managed to preserve a significant American component offered to students enrolled in the Romanian and English Language and Literature and, to a lesser extent, to those in Applied Modern Languages undergraduate programs. American Culture and Civilization, History and Geography of the U.S., American Literature are some of the core courses taught at the University of Baia Mare; also, many American writers are present in such courses as narratology or drama. A less fortunate example is the Lucian Blaga University in Sibiu, where departmental limitations and restrictions have prevented the institutionalization of a graduate or undergraduate level program.

Hoping that our brief presentations illustrate the growth and diversification of American Studies in Romania in a relatively short period of time, I would like to express my strong belief that this process of institutionalizing American Studies will continue.

\section{NOTES}

1. Under the Bologna educational reform, the American Studies undergraduate program in Bucharest will be three-year long, with a two-year MA program.

\section{INDEX}

Keywords: philosophy, popular culture, history, sociology, law, pragmatism, politics, canon, Film Studies, Mass Media, Gender, Psychoanalysis, Postmodernism, Visual Arts, Communication, Bologna, Advertising, Journalism, Business, Native American, Poetics, Feminism, American Art, South, Regionalism, African-American literature and culture, Science Fiction 